\title{
The Role Of Enterprenuerial Orientations On Micro Small Enterprises (MSEs) Performance (Study Of Indonesia MSEs Performance in a Border Area)
}

\author{
Susantiningrum, Subroto Rapih, Tri Murwaningsih \\ \{Susantiningrum@staff.uns.ac.id ${ }^{1}$,Subrotorapih_89@staff.uns.ac.id ${ }^{2}$, \\ Trimurwaningsih@staff.uns.ac.id $\left.{ }^{3}\right\}$
}

Faculty of Teacher And Training Educations, Universitas Sebelas Maret, Surakarta, Indonesia ${ }^{1}$

\begin{abstract}
The purpose of this study was to determine the effect of social capital and human capital on the performance of MSEs through entrepreneurial orientations in the Belu Regency, Indonesia. The population in this study were all MSEs in the furniture and animal husbandry sectors in Belu Regency and the number of samples in this study amounted to 250 units of MSES consisting of 2 types of furniture and animal husbandry sectors. Data analyzed using path analysis model. The reults was found, both variables (human capital and social capital), will have a greater influence on the performance of MSEs if through entrepreneurial orientation variables.
\end{abstract}

Keywords: Human capital, social capital, enterprenurial orientations, MSEs Performance.

\section{Introduction}

Micro Small Enterprises (MSEs) have a very important role in the economic growth of a country. With various characteristics possessed, MSEs are one of the types of businesses that are most able to survive in various financial crises. In addition, other characteristics that make MSEs very important in an economy especially developing countries are the majority of MSEs are labor-intensive businesses, found in all locations, especially in rural areas, more dependent on local raw materials, and the main providers of goods and services basic needs of lowincome or poor people.

Based on the description above, MSEs is a type of business that is close to the lower middle class. MSEs are considered able to solve poverty problems, especially in less developed rural areas [1] [2] [3] [4] [5]. In the context of local economic development, MSES acts as a driving force. MSEs usually grow in rural areas and with relatively little capital needed and management that tends to be simple, MSEs can be the most suitable choice for the poor [1].

Although MSEs are sufficient with simple management, innovation is still needed to continue to grow and grow sustainably. The factor of the owner or leader has a very significant role in determining the direction of MSES business. In other words, entrepreneurial orientations are an absolute requirement for the success of MSES business in order to be able to grow and develop sustainably [6] [7] [8]. [9] suggests that there are specific dimensions of entrepreneurial orientations, namely innovativeness, proactiveness, and risk taking. 
To be able to grow and develop sustainably, MSEs must manage well the three dimensions of entrepreneurial orientations. Innovations that continue to be made in improving the services or products produced, are proactive in meeting new changes and challenges, as well as the courage to take risks by seeing predetermined conditions and predictions to be so important in the success of a MSES business.

In order to support entrepreneurial orientation in business, other aspects are needed. some aspects that are very instrumental in business are aspects of social capital and human capital. These two specs are the main aspects that have a very important role in a business. Aspects of social capital will provide benefits in the development of social networks. A strong social network will facilitate the information process so that it will open wider opportunities for MSEs. The extent of the source and accuracy of information is a valuable capital in the development of a business. Therefore, social networking becomes very important to gather all information that may be very important for the company. [10] Revealed that social networks which are part of social capital are very important resources for a business organization. Through social networks, information that may be very important for the organization can be obtained [11] [12].

Human capital aspects have a very important contribution to the performance of a business [13] [14]. In short, human capital can be interpreted as the knowledge, skills, competencies, and attributes contained within an individual to facilitate the creation of personal, social and economic prosperity. In the context of business or non-business organization management, human capital can be interpreted as a process of individual development within the organization. Human capital is also a very important capital for business organizations in order to continue to grow and develop sustainably. Therefore, it is very important to continue to increase human capital in an organization.

As one of the border regions of the Republic of Indonesia, Belu Regency, East Nusa Tenggara Province, is classified as a lagging region and is in dire need of an economic driving force. Poverty is still a major problem in Belu Regency. Poverty and a high level of unemployment make Belu Regency unable to develop the region to its full potential. MSEs have a very strategic role in the economic development process of Belu Regency. But until now, the MSES sector in Belu Regency still faces various obstacles in terms of productivity. MSES performance has not been optimally developed due to several factors including lack of infrastructure, competency of human resources, technology, synergy between lines etc. These factors which until now have made MSEs in Belu District have not achieved the expected performance. So that the contraction is an optimal economic drive for the region.

The purpose of this study was to determine the effect of social capital and human capital on the performance of MSEs through entrepreneurial orientations in the Belu Regency, Indonesia.

\section{Literature Review}

\subsection{Enterprenuerial Orientations And MSEs Performance}

Entrepreneurial orientation is a strategic resource of organizations with the potential to produce competitive advantage [15]. [16] defines entrepreneurial orientation as a corporate benefit strategy to be able to compete more effectively in the same market place. Entrepreneurial orientation can also be said to be a characteristic of the company because it 
reflects the company's behavior [9]. More specifically [9] introduced a specific dimension of entrepreneurial orientation over three indicators, namely innovativeness, proactiveness, and risk taking. Innovation can be interpreted as the tendency of companies to be involved and support in developing new ideas, novelty, experiments and creative processes that can produce new technology products, services, or processes [17]. While the proactive attitude refers to an attitude that aims to anticipate and act on the wishes and needs of the future in a competition that creates the advantage of the first mover when dealing with competitors [18]. And the courage to take risks refers to the tendency to take bold steps such as entering a new market / competition that has never been done before and allocating most of the company's resources to businesses that are not yet sure of results and or dare to add more capital loans to something greater [18].

Entrepreneurial orientation is closely related to the performance of business organizations. Many studies have proven that Entrepreneurial orientation variables affect the performance of business organizations.

Meanwhile, entrepreneurial orientation will also affect the performance of the company if combined with the ease of access to capital and a dynamic environment [19]. Other studies conducted by [20] reinforce that there is a significant relationship between entrepreneurial orientation determined by company performance. In this study, the indicator used to measure leadership orientation variables is innovativeness, proactiveness, and risk taking.

\subsection{Human Capital And MSEs Performance}

The aspect of human resources is a very important element in a business and non-business organization. The quality of human resources is crucial for the development and progress of the organization. To make a business organization develop, it is necessary to develop a sustainable human resource. It is in this situation that capitalism holds a key role in business organizations. According to [21] the term human capital has been defined as a key element in increasing company assets and employees to improve productivity as well as maintain competitive advantage.

[22] Defines Human Capital as an effort to empower people with all the knowledge and skills needed to survive in a changing society. There are various definitions for interpreting huan capital. [23] Defines Human Capital as a concept that covers many dimensions and obtains points so that it becomes a fairly complex phenomenon. The European Commission defines Human Capital as knowledge, skills, competencies and attributes realized in individuals that facilitate personal, social and economic welfare.

[24] Defines human cpaital with a slightly different term according to him, human capital relates to individual knowledge and capabilities that allow for changes in action and economic growth. Individual knowledge and abilities can be obtained from various approaches. Formal training and education are one of the approaches or mechanisms of human resource development [25].

Human capital is closely related to the performance of a business organization. Human capital allows businesses to continue to grow continuously. [26] In his theoretical study developing conceptual relationship models between variables of human capital and organizational performance. In this study, it is theoretically proven that human capital has an influence on organizational performance. Human capital must be well managed and coordinated in a human capital management. Human capital management has a very important role in organizational performance. In research conducted by [27] shows empirical evidence that human capital management has a significant impact on organizational performance. 
Other evidence that shows the link between human capital and company productivity can be seen in the research conducted by [28] in the study, using data obtained from a survey of Irish companies to estimate the impact of training (part of human capital) towards company productivity. The results showed a statistically significant positive correlation between training and company productivity.

[29] Stated that the concept of human capital consists of a combination of employee competencies, employee attitudes and employee creativity. Human capital is also defined as the value of individual knowledge and talent in the organization which includes knowledge, capacity, competence, attitude, agility and intellectual creativity [26]. [30] Classify human capital in the form of competencies such as employee skills, knowledge and commitment such as loyalty to their work and company. Meanwhile [31] proposes that human capital consists of elements which include education, business experience and level of motivation. In this study, human capital consists of indicators of training, education, knowledge and expertise.

\subsection{Social Capital And MSEs Performance}

Social capital can be defined as a set of informal values and norms that are shared among members of a community group that allows collaboration between them. Social capital itself is a capability that arises from a common belief in a society or in certain parts of it. [32]. [33] Define social capital as a relational resource that is inherent in cross-sectoral personal relations, which is very useful for individual development in the social community of the organization. Social capital is closely related to networks both individually and business. In a business context, social capital provides a network that allows opportunity discovery and identification, collection and allocation of scarce resources. Briefly, [34] suggest that social capital contributes to Entrepreneurial because with a high level of social capital can reduce transaction costs between actors, information search costs, bid costs, and costs decisionmaking.

[35] Defines that social capital has three main variables, namely trust, social norms and social networking. Social trust (trust) is further divided into individual, institutional and abstract systems. Social norms are important variables to maintain social relations. The norms found in society are rules that are made to maintain commitment, fulfill obligations and bonds in society. Social networking is a form of people and a group of people who are related directly or indirectly. Social relations are also related to communication found on social networks.

Social capital is closely related to the performance of a business and non-business organization. [10] [11] Revealed that social networks which are part of social capital are very important resources for a business organization. Through social networks, information that may be very important for the organization can be obtained [11] [12]. Based on research conducted by [13] [36] [14] aspects of human capital have very important in the performance of a business.

Parameters related to social capital [37] can consist of: Participation in the network of social organizations / work, trust among others, can be seen from, adherence to norms, seen from: level of obedience towards adopted norms, concern for others, and involvement in social organization activities. The social capital of its existence needs to be added to the dimensions of cooperation or cooperation. Social capital externally is influenced by mutual trust, mutual respect and mutual benefits. While internally social capital is influenced by the existence of values that live in the community. In this study, social capital variables will be measured using 3 main indicators, namely: Trust, Social norms and social networks. 


\subsection{Proposed Model Of Relationship Between Variables}

In this study, the effects of variables will be tested which have previously been developed based on theoretical studies. In this study involved 2 independent variables 1 intervening variable and 1 dependent variable. In detail, each variable and indicator can be seen in the following table:

Table 1. Table Type Styles

\begin{tabular}{|c|c|c|c|}
\hline No. & $\begin{array}{c}\text { Types of } \\
\text { variables }\end{array}$ & $\begin{array}{c}\text { Variables`s } \\
\text { name }\end{array}$ & Indicators \\
\hline \multirow[t]{3}{*}{1.} & $\begin{array}{l}\text { Independents } \\
\text { variables }\end{array}$ & $\begin{array}{l}\text { Human capital } \\
\text { (HC) (X1) }\end{array}$ & $\begin{array}{ll}\text { a. } & \text { Training } \\
\text { b. } & \text { Education } \\
\text { c. } & \text { Knowledge } \\
\text { d. } & \text { Skills }\end{array}$ \\
\hline & & $\begin{array}{l}\text { Social capital } \\
\text { (HC) }(\mathrm{X} 2)\end{array}$ & $\begin{array}{l}\text { a. Trust } \\
\text { b. Social norm } \\
\text { c. Social networking }\end{array}$ \\
\hline & & $\begin{array}{l}\text { Enterprenuerial } \\
\text { orientations } \\
(\mathrm{E} 0)(\mathrm{X} 3)\end{array}$ & $\begin{array}{l}\text { a. Innoasi } \\
\text { b. Pro aktif } \\
\text { c. Risk taking }\end{array}$ \\
\hline 2. & $\begin{array}{l}\text { Dependent } \\
\text { Variabel }\end{array}$ & $\begin{array}{l}\text { MSES } \\
\text { Performance } \\
\text { (Perform) }(\mathrm{Y})\end{array}$ & $\begin{array}{l}\text { a. Return on capital } \\
\text { employed } \\
\text { b. Earnings per share } \\
\text { c. Sales growth }\end{array}$ \\
\hline
\end{tabular}

Furthermore, a path and variable model is arranged based on theoretical studies. Path models and hypotheses developed can be seen in the following images:

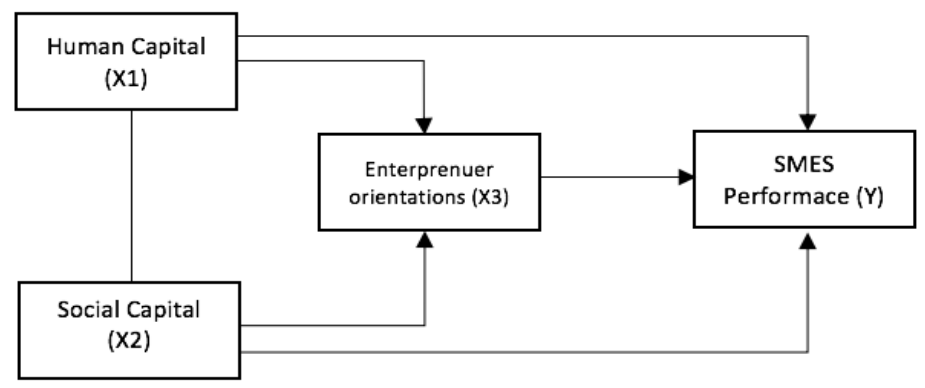

Fig. 1. Proposed of Path Model

The hypothesis in this study are as follows:

1. H1: Human Capital (X1) has a significant positive effect on Entrepreneurial Orientations (X3)

2. H2: Social Capital (X2) has a significant positive effect on Entrepreneurial Orientations (X3)

3. H3: Human Capital (X1) has a significant positive effect on the performance of MSES (Y) through the Enterprenuership Orientation (X3)

4. H4: Social Capital (X2) has a significant positive effect on the performance of MSES (Y) through the Enterprenuership Orientation (X3) 
5. H5: Human Capital (X1) has a significant direct positive effect on the performance of MSEs (Y)

6. H6: Social Capital (X2) has a significant direct positive effect on the performance of MSEs (Y)

7. H7: Entrepreneurial Orientations (X3) has a significant positive effect on the performance of MSES (Y)

\section{Research Method}

This study uses a qualitative approach. The population in this study were all MSEs in the furniture and animal husbandry sectors in Belu Regency (the outer regions of Indonesia which bordered with Republik Democratik Timor Leste), East Nusa Tenggara Province. The number of samples in this study amounted to 250 units of MSES consisting of 2 types of furniture and animal husbandry sectors. Data analyzed using path analysis model and processed using SPSS version 22 software.

\section{Results}

\subsection{Fisrt Test}

In the first structure, testing the relationship between human capital (X1) and Social capital (X2) variabe with Enterprenuerial orientations (X3) is conducted. The results of the regression analysis between the variables Human Capital (X1) and Social Capital (X2) with Entreprenuer orientation (X3) can be seen in table 2:

Table 2. Results Of Testing The Relationship Between The Variables Of Human Capital (X1) \& Social

\begin{tabular}{|c|c|c|c|c|c|c|}
\hline \multicolumn{7}{|c|}{ Capital (X2) With Entrepreneur Orientations (X3) } \\
\hline & \multirow[t]{2}{*}{ Model } & \multicolumn{2}{|c|}{$\begin{array}{l}\text { Unstandardized } \\
\text { Coefficients }\end{array}$} & \multirow{2}{*}{$\begin{array}{c}\begin{array}{c}\text { Standardized } \\
\text { Coefficients }\end{array} \\
\text { Beta } \\
\end{array}$} & \multirow[t]{2}{*}{$\mathbf{t}$} & \multirow[t]{2}{*}{ Sig. } \\
\hline & & B & Std. Error & & & \\
\hline \multirow{4}{*}{1} & (Constant) & 10.195 & 4.083 & & 2.497 & .013 \\
\hline & $\mathrm{HC}$ & .448 & .052 & .445 & 2.564 & .000 \\
\hline & $\mathrm{SC}$ & .396 & .057 & .363 & 6.982 & .000 \\
\hline & \multicolumn{6}{|c|}{ Dependent Variable: EO } \\
\hline
\end{tabular}

The data above shows that the sig value. for $\mathrm{HC}$ is 0,000 or less than 0.05 and tcount $>\mathrm{t}$ table or 2,564> 1,969 which means that the variable Human Capital (X1) has a significant positive effect on Entrepreneurial Orientations (X3)) so that based on statistical tests, the first hypothesis is accepted.

The data above shows that the sig value. for social Capital (X2) is 0.000 or less than 0.005 and tcount> ttable or 6.982> 1.969, which means that the Social capital (X2) variable has a significant positive effect on Entrepreneurial Orientations (X3) so that based on statistical tests, the second hypothesis is accepted. 


\subsection{Second Test}

In the second test, testing the relationship between human capital (X1), Social capital (X2) and Entrepreneur orientations (X3) variants was carried out jointly on the performance of MSEs (Y). The results of the regression analysis of the relationship between human capital variants (X1), Social capital (X2) and Entrepreneur orientations (X3) together on the MSES Performance $(\mathrm{Y})$ can be seen in table 3 below:

Table 3. Results of testing the relationship between human capital (X1), Social capital (X2) and Entrepreneur orientations (X3) together on the performance of MSEs (Y)

\begin{tabular}{llrrrrr}
\hline & Model & Sum of Squares & df & Mean Square & F & Sig. \\
\hline 1 & Regression & 8015.564 & 3 & 2671.855 & 233.496 & $.000^{\mathrm{b}}$ \\
Residual & 2814.936 & 246 & 11.443 & & \\
Total & 10830.500 & 249 & & &
\end{tabular}

a. Dependent Variable: Performa

b. Predictors: (Constant), EO, SC, HC

Based on the calculation results obtained by the value of Fcount $=233.496$ with a significance of 0.000 . So it can be concluded that there is a positive influence between Human Capital (X1) and Social Capital (X2) and Entrepreneur Orientations (X3) on the performance of MSEs. So that based on statistical tests, the third and fourth hypotheses are accepted.

\subsection{Third Test}

In this stage, testing the relationship between human capital (X1), Social capital (X2) and Enterprenuerial orientations (X3) variables partially on the performance of MSEs (Y). The results of the regression analysis of the relationship between human capital variabe (X1), Social capital (X2) and Entrepreneur orientations (X3) partially on the MSES Performance (Y) can be seen in the following table 4 :

Table 4. Results of testing the relationship between human capital (X1), Social capital (X2) and Enterprenuerial orientations (X3) partially on the performance of MSEs (Y)

\begin{tabular}{|c|c|c|c|c|c|c|}
\hline \multirow{2}{*}{\multicolumn{2}{|c|}{ Model }} & \multicolumn{2}{|c|}{$\begin{array}{c}\text { Unstandardized } \\
\text { Coefficients }\end{array}$} & \multirow{2}{*}{$\begin{array}{c}\text { Standardized } \\
\text { Coefficients } \\
\text { Beta }\end{array}$} & \multirow[t]{2}{*}{$\mathbf{t}$} & \multirow[t]{2}{*}{ Sig. } \\
\hline & & B & Std. Error & & & \\
\hline \multirow{5}{*}{1} & (Constant) & -.397 & 2.965 & & -.134 & .894 \\
\hline & $\mathrm{HC}$ & 196 & .043 & 193 & 1.593 & .072 \\
\hline & $\mathrm{SC}$ & .250 & .044 & .227 & 5.613 & .000 \\
\hline & EO & .574 & .046 & .769 & 12.575 & .000 \\
\hline & \multicolumn{6}{|c|}{ a. Dependent Variable: Performa } \\
\hline
\end{tabular}

The data above shows that the sig value. for human capital is 0.072 or greater than 0.05 and tcount <ttabel or $1.593<1.969$ means that the human capital variable does not directly affect the performance of MSEs so the fifth hypothesis is rejected.

The data above shows that the sig value. for social capital is 0.000 or less than 0.005 and tcount> ttable or 5.613> 1.969 means that social capital variables directly affect the performance of MSEs so that the sixth hypotsis is accepted. 
The data above also shows that the sig value. for enterprenuerial orientations is 0.000 or less than 0.005 and tcount $>$ ttable or $12.575>1.969$ means that the enterprenuerial orientations variable has a direct effect on the performance of MSEs so that the seventh hypothesis is accepted.

\subsection{Path Analysis Results}

After testing the model described in the previous section, the reconstruction of the causal relationship pathway between variables with one another is carried out. The construction of the path obtained based on the results of the analysis are as follows:

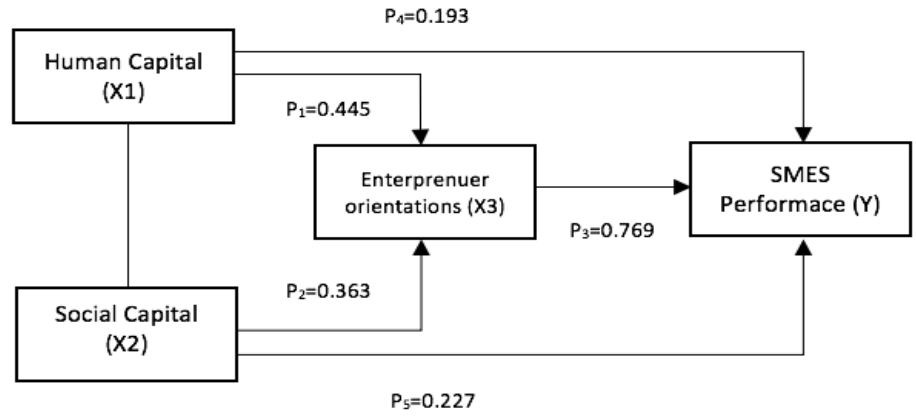

Fig. 2. Statistical decomposition model

The statistical decomposition obtained as presented in the figure above, there is an insignificant path coefficient that is between human capital and MSES performance (P4 = 0.193), while the paths P1, P2, P3 and P5 are tested significantly, therefore the P4 path is removed, so not shown in the model, the new statistical decomposition model is as follows:

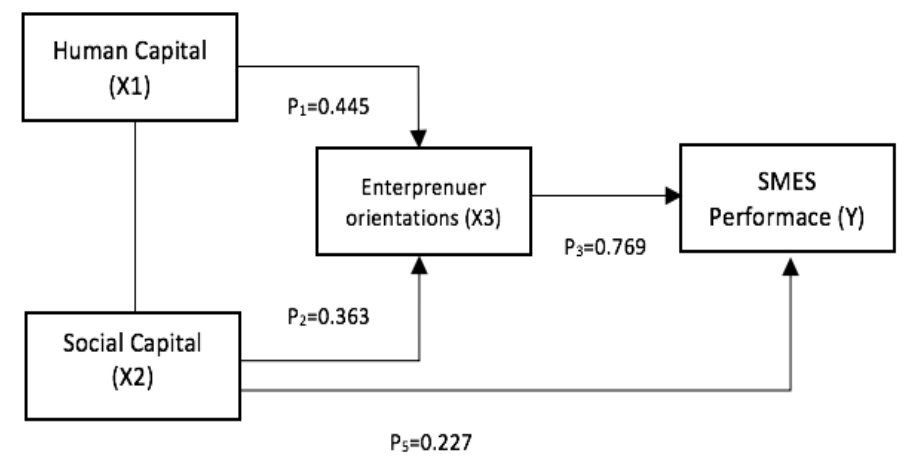

Fig. 3. Statistical decomposition model

By paying attention to Figure 3, we can then find out the direct and indirect relationships of each independent variable on the performance of MSEs.

Discussion

Based on statistical tests it is known that the variable human capital has a significant influence on Entrepreneurial orientation variables so that the first hypothesis is accepted. The results of this study also confirm research conducted by [38]. In this study it is known that human capital has a close influence on enterprenuer orientation. This research also confirms 
the research conducted by [39] which states that, human capital formed from education, has a strong influence on enterprenuer orientation.

This study also shows that social capital variables have a significant influence on the variable enterprenuer orientation. This research is in line with research conducted by [40]. In this study, social capital variables proved to have a direct influence on the variable enterprenuerial orientations. In this study, social capital variables can provide a strong influence on the three domains of entrepreneurial orientation, namely innovation, risk taking and activity. This finding is in line with the theory of [34] suggests that social capital contributes to Entrepreneurial because with a high level of social capital can reduce transaction costs between actors, information search costs, bidding costs, and decision making costs.

This study also found that there was a significant relationship between the variables of human capital, social capital and orientations towards the performance of MSEs. The variables of human capital, social capital and enterprenuerial orientations in this study proved jointly also have a significant influence on the performance of MSEs. This shows that these three variables have a very important role in the success of a MSES. But interestingly, in the partial analysis the three independent variables have a different impact on the performance of MSEs.

Social capital variables and entrepreneur orientation are directly proven to have an effect on MSES performance. This is in line with research conducted by [4][1][20][13][36][42][14][43] which states that social capital and Entrepreneurial orientation provide important contributions to the success of a business organization.

In partial testing, the variable human capital provides different results with the other two independent variables. In this study the variable human capital does not directly affect the performance of MSEs. In other words, in this study the variable human capital will only affect the performance of MSEs if through the variable enterprenuerial orientations. So that human capital will be very good if it is used to develop and improve Entrepreneurial orientations and will further contribute to the improvement of MSES performance. This actually also happens to social capital variables. Although social capital variables directly affect the performance of MSEs, if the socila capital variable through entrepreneurial variables or orientation will have a greater influence on the performance of MSEs.

This finding also explains that any increase in human capital, will provide a significant change in the variable entrepreneurial orientation.

\section{Conclusion}

This study was found that the variables of human capital and social capital had a significant influence on the variables of entrepreneurial orientations. these three variables together also have a significant influence on the MSEs performance. But partially, human capital does not have a direct influence on the MSEs performance. While social capital and entrepreneurial orientations have a direct influence. However, both variables (human capital and social capital) will have a greater influence on the MSEs performance if through entrepreneurial orientation variables.

Acknowledgment. This research would not have been possible without the financial support of the Institute of Research And Community Service, Sebelas Maret Univesity. We are especially indebted to Prof. Dr. Ravik Karsidi, MS, Rector of Sebelas Maret University, and 
Prof. Sulistyo Saputro, Ph.D Head of Institute of Research And Community Service, Sebelas Maret Univesity who have been supportive of this research.

\section{References}

[1] Ayandibu, A. O., \& Houghton, J. (2017). The role of Small and Medium Scale Enterprise in local economic development (LED). Journal of Business and Retail Management Research, 11(2).

[2] Ben-Caleb, E., Faboyede, O. S., \& Fakile, A. S. (2013). Empowering small and medium scale enterprises in Nigeria: A key poverty alleviation strategy. International Journal of Business and Management Invention, 2(5), 6-12.

[3] Abdullahi, M. S., Tahir, I. M., Aliyu, R. L., \& Abubakar, A. (2015). Strengthening Small and Medium Scale Enterprises (SMEs) For Poverty Alleviation in Nigeria. IOSR Journal Of Humanities And Social Science (IOSR-JHSS), 20(6), 101-110.

[4] Sharafat, A. L. I., Rashid, H., \& Khan, M. A. (2014). The role of small and medium enterprises and poverty in Pakistan: An empirical analysis. Theoretical and Applied Economics, $18(4$ (593)), 67-80.

[5] Oyelana, A. A., \& Fiseha, G. G. (2014). An Investigation into the Effect of Small and Medium Enterprises (SMEs) on the Socio-Economic Development of Alice in Eastern Cape Province, South Africa. Mediterranean Journal of Social Sciences, 5(23), 674.

[6] Rauch A., Wiklund, J., Lumpkin, G.T., \& Frese, M. (2009). Entrepreneurial orientation and business performance: An assessment of past research and suggestions for the future. Entrepreneurship Theory and Practice, (5), 761- 786.

[7] Keh, HT, Nguyen, TTM \& Ng, HP 2007, 'The effects of entrepreneurial orientation and marketing information on the performance of SMEs', Journal of Business Venturing, vol. 22, pp. 592-611.

[8] Wang, C. 2008. Entrepreneurial orientation, learning orientation, and firm performance. Entrepreneurship Theory and Practice, 32(4): 635-656.

[9] Miller, D. (1983). The correlates of entrepreneurship in three types of firms. Management Science, 29(7), 770-791.

[10]García Sánchez, E., García Morales, V. J., \& Martín-Rojas, R. (2017). Do social networks and technological capabilities help knowledge management?. Journal of technology management \& innovation, 12(4), 65-69.

[11]Fernandez Perez, V., Martin Rojas, R. \& Garcia Sanchez, E. (2011). Redes sociales empresariales: ¿Una oportunidad o una pérdida de tiempo en la sociedad del conocimiento? Gestión Joven, 7, 38-50.

[12]Fliaster, A. \& Spiess, J. (2008). Knowledge mobilization through so- cial ties: The cost-benefit analysis. Schmalenbach Business Review, 60(1), 99-117.

[13] Marimuthu, M., Arokiasamy, L., \& Ismail, M. (2009). Human capital development and its impact on firm performance: Evidence from developmental economics. Journal of international social research, 2(8).

[14] Ojokuku, R. M., \& Sajuyigbe, A. S. (2015). Effect of human capital development on the performance of small and medium scale enterprises in Nigeria. Journal of Emerging Trends in Economics and Management Sciences, 6(1), 88-93.

[15]Nuvriasari, A., Wicaksono, G., \& Sumiyarsih, S. (2018). Peran Orientasi Pasar, Orientasi Kewirausahaan Dan Strategi Bersaing Terhadap Peningkatan Kinerja Ukm. Ekuitas: Jurnal Ekonomi Dan Keuangan, 19(2), 241-259

[16]Porter M., 1980, Competitive Strategy, Free Press, New York. 
[17]Li Y , Zhao Y, T an J, Liu Y (2008). Moderating Effects of Entrepreneurial Orientation on Market Orientation-Performance Linkage: Evidence from Chinese Small Firms. J. Small Bus. Manage., 46(1), 113-133

[18]Lumpkin GT , Dess GG (2001). Linking two dimensions of entrepreneurial orientation to firm performance: the moderating role of environment and industry life cycle. J. Bus. Venturing, 16(5), 429- 451.

[19]Wiklund, J., \& Shepherd, D. (2005). Entrepreneurial orientation and small business performance: a configurational approach. Journal of business venturing, 20(1), 71-91.

[20]Gosselin Maurice, (2005). An Empirical Study of Performance Measurement in Manufacturing Firm, International Journal of Productivity and Performance Management, Vol. 54 No.5/6.pp.419-437

[21] Simkovic, M. (2013). Risk-Based Student Loans. Washington and Lee Law Review 70 (1): 527. SSRN 1941070.

[22] Hamid, N. A., \& Zaman, H. B. (2009). Human Capital Indicators: Towards Achieving a Knowledge Society In Malaysia. Napsipag. org.

[23] Natoli, R. (2008). Indicators of economic and social progress: An assessment and an alternative. Doctoral thesis, School of Applied Economics, Faculty of Business and Law, Victoria University, Melbourne, Australia.

[24]Coleman. J. S. (1988). Social capital in the creation of human capital. American Journal of Sociology, vol. 94, pp. 95-120.

[25]Samad, S. (2013). Assessing the contribution of human capital on business performance. International Journal of Trade, Economics and Finance, 4(6), 393.

[26] Alnachef, T. H., \& Alhajjar, A. A. (2017). Effect of Human Capital on Organizational Performance: A Literature Review. International Journal of Science and Research (IJSR). Vol 6 (8).

[27]Jamal, W., \& Saif, M. I. (2011). Impact of human capital management on organizational performance. European Journal of Economics, Finance and Administrative Sciences, 5(34), 13309-13315.

[28]Barrett,A. And O'connell, J.P (2001) Does Training generally works? The returns to in- company training, Industrial And Labor Relations Review, 54(3), pp 647-662.

[29]Chen, J, Zhu, Z, and Xie, H, Y. (2004). Measuring intellectual capital: a new model and empirical study. Journal of Intellectual Capital, vol. 5, no. 1, pp. 195-211.

[30] Rodrigues, H. S, Dorrego, P. F and Jardon, C. F. (2010). The influence of human capital on the innovativeness of firms, The International Business and Economics Research Journal, vol. 9, no. 9, pp. 53-63.

[31]Pena, I. (2002). Intellectual capitaland business start-up success, Journal of Intellectual Capital, vol. 3, no. 2, pp. 180-198.

[32]Fukuyama, Francis. 2002. Trust: Kebajikan Sosial dan Penciptaan Kemakmuaran. Yogyakarta : Qalam.

[33] Tsai, Wenpin, Sumantra Ghoshal. (2007). Social Capital and Value Creation : The Role of Intrafirm Networks : The Academy of Management Journal, Vol.41, No.4, pp. 464-476

[34]Doh, Soogwan dan Edmund J.Zolnik, 2011, Social Capital and Entrepreneurship : An Exploratory Analysis, African Journal of Business management Vol.5 (12), pp. 4961-4975 [35] Saputro GE., 2006, Modal Sosial dalam Pengelolaan Sumberdaya Hutan pada Masyarakat Adat Kasepuhan Banten Kidul, Departemen Manajemen Hutan, Fakultas Kehutanan, Institut Pertanian Bogor

[36] Muda, S., \& Rahman, M. R. C. A. (2016). Human capital in SMEs life cycle perspective. Procedia Economics and Finance, 35, 683-689. 
[37]Primadona, 2012, Penguatan Modal Sosial untuk Pemberdayaan Masyarakat dalam Pembangunan Pedesaan (Kelompok Tani Kecamatan Rambatan), Jurnal Polibisnis, Volume 4 No. 1 April 2012, Politeknik Negeri Padang

[38]Neira, I., Portela, M., Cancelo, M., \& Calvo, N. (2013). Social and human capital as determining factors of entrepreneurship in the Spanish Regions. Investigaciones Regionales, 26 (2013) - P.115-139

[39] Maresch, D., Harms, R., Kailer, N., \& Wimmer-Wurm, B. (2016). The impact of entrepreneurship education on the entrepreneurial intention of students in science and engineering versus business studies university programs. Technological forecasting and social change, 104, 172-179.

[40] Wimba, I. G. A. (2015). Effect Of Social Capital On Entrepreneurial Orientation And Transaction Cost To Improve Firm Performance In Wooden Craft Smes In Bali ProvinceIndonesia. International Journal of Economics, Commerce and Management. Vol. III, Issue 10, October 2015.

[41]Pratono, A. H., Tee, C. W., Syahchari, D. H., Nugraha, A. T., Mat, N. K. N., \& Fitri, H. (2013). The Direct Effect of Entrepreneurial Orientation and Innovation Success on Firm Performance. American Journal of Economics, 3(1), 1-6.

[42] Widarni, E. L. (2015). The influence of human capital elements on performance: Evidence from West Java SMEs. Journal of Economics and Sustainable Development, 16(4), 196-201.

[43]Ukenna, S., Ijeoma, N., Anionwu, C., \& Olise, M. C. (2010). Effect of investment in human capital development on organisational performance: empirical examination of the perception of small business owners in Nigeria. European Journal of Economics, Finance and Administrative Sciences, 93-107. 